\title{
PENGARUH PUSH, PULL, DAN MOORING TERHADAP SWITCHING INTENTION PADA KONSUMEN PENGGUNA WIFI DI ERA PANDEMI COVID-19
}

\author{
Adita Primadana Sugandha \\ Universitas Negeri Surabaya \\ adita.17080574113@mhs.unesa.ac.id \\ Tias Andarini Indarwati \\ Universitas Negeri Surabaya \\ tiasindarwati@unesa.ac.id
}

\begin{abstract}
Internet use during the current pandemic is increasing, and most are done online. Work From Home (WFH) and School From Home (SFH) require stable and smooth internet. In addition to the internet, smartphones also play an essential role in people's daily lives during restrictions due to the pandemic. This study aims to analyze and discuss the effect of push, pull and mooring on switching intention. This study uses a push-pull-mooring model with an approach through switching intention. Respondents in this study were at least 20 years old. Due to this age, respondents have entered the adult stage in switching intentions from internet data packages to wifi. The sample used is 110 respondents - the sampling method used non-probability sampling with the judgmental sampling method. The analysis technique uses multiple linear regression with SPSS26 software. Based on the results obtained, it is known that the push variable on switching intention to use wifi has a positive effect. The pull variable has a positive impact on switching intention to use wifi. When the push and pull are getting stronger, consumers will switch. Mooring variable does not affect internet data packet switching intention to private wifi. This result shows that the switching intention of data packets to use wifi privately at home is relatively high. Due to using private wifi, you can access or surf the internet at a stable speed compared to data packet internet, in contrast to using data packet internet whose network is unstable.
\end{abstract}

Keywords: mooring effect; pull effect; push effect; switching intention; wifi.

\section{PENDAHULUAN}

Dunia saat ini sedang dilanda oleh wabah Corona Virus Desease 2019 (Covid-19), virus ini disebabkan corona virus yang diberi nama SARS-CoV2. Covid-19 ini pertama kali terdeteksi di Wuhan, Tiongkok pada Desember 2019 dan ditetapkan sebagai pandemi global oleh WHO pada 11 Maret 2020 (Djkn.kemenkeu, 2020). Pandemi virus Covid-19 ini telah menyebabkan berbagai macam persoalan, mulai dari persoalan ekonomi, sosial, politik, hingga ketenagakerjaan (Gajimu.com, 2020). Menanggapi pandemi tersebut, beberapa negara telah menerapkan penguncian dan kebijakan social distancing, termasuk juga Indonesia yang telah menerapkan social distancing dan stay at home. Kebijakan tersebut berupa Work From Home (WFH), School From Home (SFH) dan ibadah di rumah, secara berurutan untuk menghentikan penyebaran Covid-19 (Putri \& Irwansyah, 2020). Perusahaan di Indonesia mulai menerapkan WFH pada t16 Maret 2020, kebijakan WFH mendorong konsumsi internet yang meningkat (Jasmine, 2020).

Internet merupakan jaringan komunikasi yang terhubung dalam suatu media elektronik. Akses pada internet dapat dibedakan menjadi dua jenis yaitu data seluler dan wifi. Kelemahan pada data seluler yaitu jaringan koneksi internetnya tidak begitu stabil sesuai dengan kualitas sinyal yang diterima oleh smartphone, kelebihan dari wifi adalah stabilitas koneksi namun kekurangannya yaitu jangkauan sangat terbatas (Gizmologi.id, 2019). Dengan meningkatkan kualitas layanan, dapat memengaruhi nilai dari konsumen (F. Lai et al., 2009). Kualitas layanan mengukur seberapa baik layanan diberikan sesuai dengan harapan konsumen (Zhao \& Di Benedetto, 2013). Perusahaan digital Akamai menunjukkan lalu lintas internet di Indonesia mengalami pertumbuhan sebesar 73 persen pada kuartal I-2020 dan meningkat 139 persen pada kuartal II-2020 (Akurat.co, 2020). Masa pandemi, provider IndiHome yang mengalami peningkatan permintaan pemasangan baru hingga 47 persen dibandingkan dengan sebelum adanya pandemi (market.bisnis.com, 2020). Kenaikan konsumen untuk pemasangan wifi mengalami 
Adita Primadana Sugandha \& Tias Andarini Indarwati. Pengaruh Push, Pull, dan Mooring terhadap Switching Intention pada Konsumen Pengguna Wifi di Era Pandemi Covid-19

peningkatan dua kali lipat dibandingkan sebelum pandemi, sebagian besar peningkatan permintaan dari existing costumer (newssetup.kontan.co.id, 2021). Sebuah perusahaan ISP (Internet Service Provider) pasti memiliki strategi untuk menghadapi situasi permintaan yang tinggi. Strategi yang tepat dapat memenuhi sesuai dengan permintaan konsumen, apabila konsumen tidak merasa puas terhadap pelayanan yang diberikan maka konsumen akan beralih pada penyedia layanan ISP lain yang dianggapnya menarik. (Thaichon et al., 2014)

Berdasarkan fenomena tersebut, didapatkan adanya fenomena switching intention yang terjadi dari konsumen internet paket data ke wifi. Switching intention adalah tingkat kemungkinan atau kepastian konsumen akan beralih dari penyedia yang saat ini digunakan ke penyedia jasa baru (Bansal et al., 2005). Ketika konsumen melakukan switching antara dua penyedia layanan dalam waktu tertentu, maka konsumen tersebut melakukan sebuah migrasi (Bolye, \& Halfacree, 1998). Menurut Hou et al. (2009), migrasi dapat diklarifikasikan menjadi dua jenis yaitu sementara dan permanen. Konsep migrasi merupakan fenomena perilaku berpindahnya konsumen dari suatu penyedia layanan dan mayoritas konsumen beralih secara sukarela, hanya sebagian kecil berpindah karena keterpaksaan (Bansal et al., 2005). Perilaku switching yang dilakukan konsumen dapat didalami dengan kerangka push-pullmooring (PPM) untuk menyatukan proses switching konsumen. PPM merupakan model yang berasal dari penelitian tentang migrasi konsumen (Moon, 1995). Push adalah faktor yang mendorong konsumen untuk switching dari penyedia layanan saat ini dan pull merupakan faktor yang menarik konsumen untuk menuju ke penyedia layanan baru, sedangkan mooring adalah faktor yang membuat konsumen menghambat untuk bermigrasi (Bogue, 1969; Hsieh et al., 2012). Berdasarkan latar belakang di atas, penelitian ini bertujuan untuk menganalisis dan membahas pengaruh push, pull dan mooring pada pengguna data yang mempunyai keinginan beralih ke wifi.

\section{KAJIAN PUSTAKA DAN PENGEMBANGAN HIPOTESIS}

\section{Switching Intention}

Switching intention adalah konsep yang berlawanan pada niat membeli kembali, konsep ini mengartikan bahwa konsumen mempunyai niat untuk beralih dari penyedia layanan yang saat ini digunakan ke layanan lain (Ganesh et al., 2000). Perilaku switching intention merupakan konsep sentral dalam pemasaran yang mengacu pada migrasi konsumen antara penyedia layanan (Parthasarathy \& Keaveney, 2001). Produk atau layanan jasa yang digunakan saat ini tidak memenuhi keinginan konsumen, maka konsumen melakukan switching untuk memilih produk atau jasa yang memenuhi keinginannya tersebut (Mcalister, 2012)

\section{Push Effect}

Push effect menunjukkan kekuatan yang mendorong orang menjauh dari tempat asalnya menuju tempat yang baru disebut migrasi konsumen (Moon, 1995). Penelitian migrasi konsumen juga menganggap kepuasan dan tidak kepuasan sebagai faktor pendorong utama yang mendorong konsumen menjauh dari penyedia layanan yang digunakan sekarang (Bansal et al., 2005). Hsieh et al. (2012) menyatakan bahwa push effect didapatkan dari konsumen merasa tidak nyaman dengan penyedia layanan sekarang sehingga konsumen meningkatkan switching intention pada penyedia layanan baru.

\section{Pull Effect}

Pull effect mencerminkan kekuatan yang menarik orang ke suatu tujuan (Moon, 1995). Bogue, (1969) menyatakan pull effect merupakan faktor positif yang menarik calon migran ke tujuan tertentu, seperti datang, kesempatan kerja yang lebih baik, atau lingkungan yang nyaman. Pull effect tersebut meliputi perkembangan dan kesempatan kerja yang lebih baik, pendapatan yang lebih tinggi dan kenyamanan yang dirasakan konsumen (Bansal et al., 2005).

\section{Mooring Effect}

Mooring effect merupakan penghambat yang dipengaruhi oleh beberapa penyebab yang dirasakan konsumen, sehingga konsumen mempertimbangkan kembali untuk switching intention (Hou et al., 2011). Menurut Jung et al. (2017) mooring effect tidak hanya dipengaruhi oleh diri sendiri, tetapi juga bisa terpengaruh sosial dan lingkungan. Mooring effect yang diidentifikasi dalam penelitian tentang 
switching adalah switching costs yang dirasakan oleh konsumen (Jones et al., 2000; Kim et al., 2004; Ye \& Potter, 2011).

\section{Hubungan antar Variabel}

Lai et al. (2012) menyatakan bahwa push effect memiliki pengaruh positif terhadap switching intention. Penelitian tersebut menjelaskan bahwa ketika konsumen tidak merasakan kenyamanan terhadap penyedia layanan yang digunakan saat ini, maka konsumen akan terdorong untuk switching ke penyedia layanan baru. Chang et al. (2017) menjelaskan bahwa push effect berpengaruh secara positif pada switching intention, sehingga menyebabkan perpindahan konsumen dapat didefinisikan sebagai kesediaan konsumen untuk berhenti menggunakan penyedia layanan yang digunakan saat ini dan menggunakan layanan yang baru. Zengyan et al. (2009) menunjukkan push effect berpengaruh secara positif pada switching intention. Push effect dalam penelitian layanan sering mencakup persepsi negatif dari penyedia layanan yang digunakan saat ini, seperti low service quality, pricing problem, low satisfaction, dan low trust (Jung et al., 2017). Push effect tersebut menciptakan konsumen untuk switching.

\section{H1: Push effect berpengaruh positif terhadap switching intention.}

Pada penelitian ini, pull effect menunjukkan kekuatan menarik untuk mengundang konsumen beralih dengan indikator alternative attractiveness dan peer influence (Lai et al., 2012). Bansal et al. (2005) dan Hou et al. (2009) menunjukkan bahwa alternative attractiveness memiliki pengaruh pada switching intention. Bansal et al. (2005) menyatakan bahwa pull effect dalam teori migrasi dapat digambarkan sebagai faktor positif terhadap switching intention. Penelitian tersebut menjelaskan bahwa konsumen melakukan migrasi pada penyedia layanan baru dengan tujuan yang membuat konsumen tertarik. Hasil penelitian serupa dinyatakan Keaveney (1995) bahwa pull effect dapat dinyatakan sebagai hasil pull effect dari penyedia layanan baru itu sendiri yang membuat konsumen untuk switching intention. Penelitian lain yang menyatakan hal serupa yaitu penelitian Jung et al. (2017) dan Chang et al. (2017) bahwa pull effect memiliki dampak positif pada switching intention. Pada penelitian tersebut dijelaskan bahwa pull effect sebagai faktor terbesar yang dirasakan konsumen untuk melakukan switching intention pada penyedia layanan baru.

Konsumen bertukar informasi dan rekomendasi dengan individu lain yang terhubung dengan mereka, sehingga pertukaran tersebut dapat memengaruhi konsumen untuk switching (Retaildive.com 2017). Ketika konsumen menerima informasi dari peer influence, mereka cenderung switching untuk mengeksplorasi aktifitas, lingkungan atau hubungan baru. Konsumen lebih cenderung tertarik untuk switching jika terjadi tarikan yang kuat dari pengaruh peer influence dan alternative attractiveness (Chiu et al., 2011 \& Zengyan et al., 2009).

\section{H2: Pull effect berpengaruh positif terhadap switching intention.}

Hsieh et al. (2012) menyatakan mooring effect berpengaruh negatif pada switching intention. Peneltian tersebut menjelaskan ketika konsumen menghadapi switching costs ketika melakukan switching pada penyedia layanan baru dan konsumen memiliki past experience yang serupa tetapi konsumen merasa tidak puas, maka konsumen cenderung menetap pada layanan yang digunakan sekarang. Penelitian serupa juga disampaikan Bansal et al. (2005); Chiu et al. (2011) bahwa mooring effect memengaruhi secara negatif pada switching intention.

Chang et al. (2017) menyebutkan bahwa mooring effect berpengaruh negatif terhadap switching intention konsumen. Penelitian tersebut menjelaskan switching costs merupakan salah satu faktor terjadinya penghambat konsumen melakukan switching pada penyedia layanan baru. Hsieh et al. (2012) menjelaskan, selain switching costs ada faktor lain yaitu past experience yang dirasakan konsumen. Ketika konsumen dengan pengalaman masa lalunya menggunakan wifi ditempat umum mereka merasa nyaman, maka mereka tidak akan beralih. Sebaliknya, jika konsumen pengalaman masa lalu yang gagal. Konsumen akan melakukan switching. Karena past experience memberikan pengaruh yang berbeda 
Adita Primadana Sugandha \& Tias Andarini Indarwati. Pengaruh Push, Pull, dan Mooring terhadap Switching Intention pada Konsumen Pengguna Wifi di Era Pandemi Covid-19

kepada setiap individu, tergantung pada individu konsumen. Penelitian ini menyertakan past experience menjadi indikator pada mooring effect.

H3: Mooring effect berpengaruh negatif terhadap switching intention.

Rancangan penelitian yang digunakan untuk mengetahui bagaimana pengaruh push, pull dan mooring terhadap switching intention ditunjukkan pada Gambar 1.

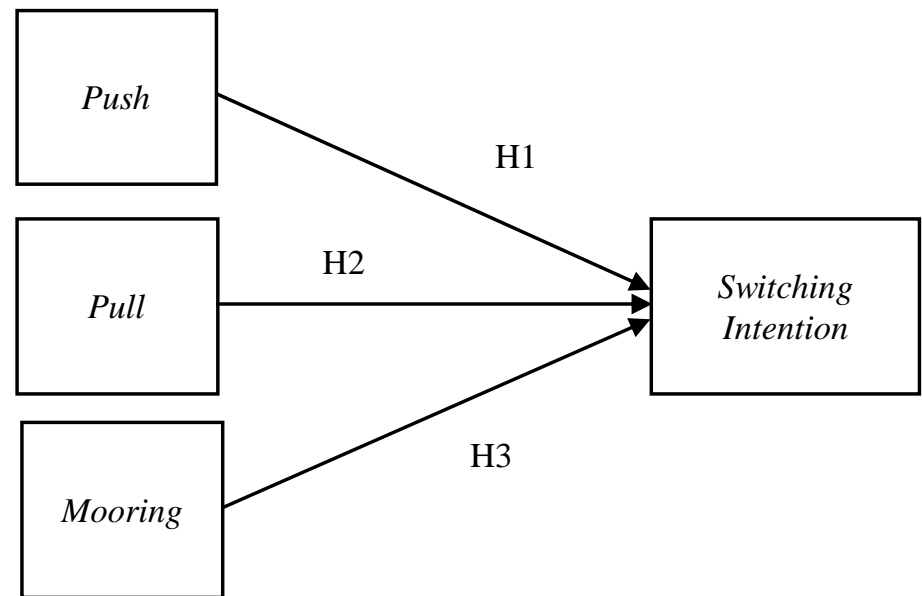

Gambar 1. MODEL PENELITIAN

\section{METODE PENELITIAN}

Pada penelitian ini menggunakan rancangan penelitian klasifikasi konklusif. Jenis rancangan penelitian yang digunakan dalam penelitian ini adalah penelitian atau riset kausal. Data primer diperoleh dari hasil jawaban responden, data sekunder diperoleh melalui studi pustaka literatur yang digunakan untuk melengkapi data primer. Populasi pada penelitian ini dengan karakteritik responden adalah seseorang yang berusia minimal 20 tahun dan seseorang yang sebelumnya menggunakan paket internet data ingin beralih menggunakan wifi. Responden dalam penelitian ini berjumlah 110 responden, serta menggunakan teknik sampling yang digunakan dalam penelitian ini adalah non-probability sampling dengan metode judgemental sampling. Teknik pengumpulan data berupa kuesioner online yang didistribusikan melalui google form. Skala pengukuran menggunakan skala Likert. Kemudian instrumen tersebut diuji untuk mengetahui validitas dan reliabilitas. Teknik analisis menggunakan regresi linear berganda dan menggunakan software SPSS 26.

\section{HASIL DAN PEMBAHASAN}

\section{Deskripsi Responden}

Karakteristik responden adalah konsumen internet paket data di Surabaya. Karakteristik lain yang digunakan yaitu konsumen yang mempunyai keinginan beralih dari internet paket data ke wifi pribadi. Total keseluruhan responden yang berpartisipasi dalam penelitian ini berjumlah 110 responden. Diketahui bahwa responden berjenis kelamin pria dan wanita memiliki jumlah tidak jauh berbeda. Responden dengan jenis kelamin pria sebanyak 59 orang (45\%) dan hasil perolehan responden dari jenis kelamin wanita sebanyak 61 orang $(55 \%)$. Sedangkan berdasarkan usia yang mendominasi adalah usia 20 - 25 tahun dengan jumlah 97 orang (88\%). Dari hasil yang terkumpul dalam penelitian ini, pada karakteristik lainnya yang mendominasi yaitu 77 orang (70\%) lulusan SMA sederajat, 69 orang (63\%) pekerjaan mereka adalah mahasiswa 69 orang (63\%), pengeluran perbulan < Rp1.000.000 47 orang $(43 \%)$.

Tabel 1. 


\section{VARIABEL, INDIKATOR, DAN ITEM PENELITIAN}

\begin{tabular}{|c|c|c|}
\hline Variabel & Indikator & Pernyataan \\
\hline \multirow{21}{*}{$\begin{array}{l}\text { Push (X1) } \\
\text { (J. Jung et } \\
\text { al., 2017) }\end{array}$} & Low Service & Menggunakan internet dari paket data sering terputus $\left(\mathrm{X}_{1.1 .1}\right)$ \\
\hline & Quality $\left(\mathrm{X}_{1.1}\right)$ & $\begin{array}{l}\text { Kecepatan mengunduh dan mengunggah menggunakan paket data cukup } \\
\text { lambat, tidak memenuhi harapan saya }\left(\mathrm{X}_{1.1 .2}\right)\end{array}$ \\
\hline & & Menurut saya kecepatan internet paket data tidak stabil $\left(\mathrm{X}_{1.1 .3}\right)$ \\
\hline & & $\begin{array}{l}\text { Operator provider paket data pilihan saya tidak begitu menguasai tentang } \\
\text { permasalahan jaringan yang saya alami }\left(\mathrm{X}_{1.1 .4}\right)\end{array}$ \\
\hline & & $\begin{array}{l}\text { Ketika saya komplain, operator provider paket data tidak menanggapi dengan } \\
\text { cepat }\left(\mathrm{X}_{1.1 .5}\right)\end{array}$ \\
\hline & & Provider paket data menyediakan informasi yang tidak lengkap $\left(\mathrm{X}_{1.1 .6}\right)$ \\
\hline & & $\begin{array}{l}\text { Provider paket data tidak menyediakan informasi terbaru tentang produknya } \\
\left(\mathrm{X}_{1.1 .7}\right)\end{array}$ \\
\hline & & $\begin{array}{l}\text { Provider paket data tidak memberikan informasi yang penting tentang } \\
\text { produknya }\left(\mathrm{X}_{1.1 .8}\right)\end{array}$ \\
\hline & & $\begin{array}{l}\text { Saya merasa informasi pribadi saya tidak dilindungi oleh provider paket data } \\
\left(\mathrm{X}_{1.1 .9}\right)\end{array}$ \\
\hline & & $\begin{array}{l}\text { Saya merasa informasi yang berhubungan dengan keuangan saya tidak } \\
\text { dilindungi oleh provider paket data }\left(\mathrm{X}_{1.1 .10}\right)\end{array}$ \\
\hline & & $\begin{array}{l}\text { Saya melakukan transaksi menggunakan provider paket data tidak merasa } \\
\text { aman }\left(\mathrm{X}_{1.1 .11}\right)\end{array}$ \\
\hline & Prici & Provider paket data pilihan saya memberikan harga yang mahal $\left(\mathrm{X}_{1.2 .1}\right)$ \\
\hline & $\begin{array}{l}\text { Problem } \\
\left(\mathrm{X}_{1.2}\right)\end{array}$ & $\begin{array}{l}\text { Provider paket data pilihan saya memberikan variasi harga paket data yang } \\
\text { sedikit }\left(\mathrm{X}_{1.2 .2}\right)\end{array}$ \\
\hline & & $\begin{array}{l}\text { Provider paket data pilihan saya tidak menyimpan catatan transaksi saya } \\
\text { sebelumnya }\left(\mathrm{X}_{1.2 .3}\right)\end{array}$ \\
\hline & Low & Saya merasa provider paket data pilihan saya tidak tepat $\left(\mathrm{X}_{1.3 .1}\right)$ \\
\hline & $\begin{array}{l}\text { Satisfaction } \\
\left(\mathrm{X}_{1.3}\right)\end{array}$ & $\begin{array}{l}\text { Saya tidak puas dengan provider paket data yang selama ini saya gunakan } \\
\left(\mathrm{X}_{1.3 .2}\right)\end{array}$ \\
\hline & & $\begin{array}{l}\text { Saya merasa tidak senang dengan provider paket data yang selama ini saya } \\
\text { gunakan }\left(\mathrm{X}_{1.3 .3}\right)\end{array}$ \\
\hline & & $\begin{array}{l}\text { Pelayanan dari provider paket data yang selama ini saya gunakan tidak } \\
\text { memuaskan }\left(\mathrm{X}_{1.3 .4}\right)\end{array}$ \\
\hline & $\begin{array}{l}\text { Low } \\
\left(\mathrm{X}_{1.4}\right)\end{array}$ & $\begin{array}{l}\text { Saya tidak mempercayai sepenuhnya kebutuhan internet saya pada paket data } \\
\left(\mathrm{X}_{1.4 .1}\right)\end{array}$ \\
\hline & & $\begin{array}{l}\text { Saya merasa tidak dapat mengandalkan pelayanan dari provider paket data } \\
\text { pilihan saya }\left(\mathrm{X}_{1.4 .2}\right)\end{array}$ \\
\hline & & provider paket data pilihan saya bisa menipu saya dengan cara \\
\hline \multirow{7}{*}{$\begin{array}{l}\text { Pull (X2) } \\
\text { (J. Y. Lai et } \\
\text { al., 2012) }\end{array}$} & $\begin{array}{l}\text { Peer } \\
\text { Influence }\end{array}$ & $\begin{array}{l}\text { Teman saya merekomendasikan kepada saya untuk beralih menggunakan } \\
\text { berlangganan pada provider wifi }\left(\mathrm{X}_{2.1 .1}\right)\end{array}$ \\
\hline & $\left(\mathrm{X}_{2.1}\right)$ & $\begin{array}{l}\text { Teman saya menyatakan menggunakan berlangganan provider wifi lebih } \\
\text { menguntungkan }\left(\mathrm{X}_{2.1 .2}\right)\end{array}$ \\
\hline & & an puas berlangganan pada provider wifi $\left(\mathrm{X}_{2.1 .3}\right)$ \\
\hline & Alternative & \\
\hline & $\begin{array}{l}\text { Attractiveness } \\
\left(\mathrm{X}_{2,2}\right)\end{array}$ & $\begin{array}{l}\text { Saya akan lebih bersemangat menjelajahi internet jika saya berlangganan pada } \\
\text { provider wifi }\left(\mathrm{X}_{2.2 .2}\right)\end{array}$ \\
\hline & & $\begin{array}{l}\text { Saya akan lebih nyaman menjelajahi internet jika saya berlangganan pada } \\
\text { provider wifi }\left(\mathrm{X}_{2.2 .3}\right)\end{array}$ \\
\hline & & $\begin{array}{l}\text { Menggunakan wifi membuat saya merasa tertarik untuk menjelajahi internet } \\
\left(\mathrm{X}_{2.2 .4}\right)\end{array}$ \\
\hline \multirow{3}{*}{$\begin{array}{l}\text { Mooring } \\
\text { (X3) } \\
\text { (Hsieh } \text { et al., } \\
\text { 2012) }\end{array}$} & $\begin{array}{l}\text { Switching } \\
\text { cost }\left(\mathrm{X}_{3.1}\right)\end{array}$ & $\begin{array}{l}\text { Untuk beralih menggunakan berlangganan wifi saya membutuhkan biaya } \\
\text { mahal }\left(X_{3.1 .1}\right)\end{array}$ \\
\hline & & Saya merasa beralih menggunakan berlangganan wifi akan menyebabkan \\
\hline & & $\begin{array}{l}\text { Saya merasa beralih menggunakan berlangganan wifi akan membutuhkan } \\
\text { banyak waktu dan tenaga. }\left(\mathrm{X}_{3.13}\right)\end{array}$ \\
\hline
\end{tabular}


Adita Primadana Sugandha \& Tias Andarini Indarwati. Pengaruh Push, Pull, dan Mooring terhadap Switching Intention pada Konsumen Pengguna Wifi di Era Pandemi Covid-19

\begin{tabular}{lll}
\hline \multicolumn{1}{c}{ Variabel } & \multicolumn{1}{c}{ Indikator } & \multicolumn{1}{c}{ Pernyataan } \\
\hline & $\begin{array}{l}\text { Past } \\
\text { Experience } \\
\left(\mathrm{X}_{3.2}\right)\end{array}$ & $\begin{array}{l}\text { Pengalaman saya menggunakan wifi di tempat umum kurang memuaskan } \\
\left(\mathrm{X}_{3.2 .1}\right)\end{array}$ \\
$\begin{array}{l}\text { Keinginan } \\
\text { Switching } \\
\text { Intention }\end{array}$ & $\begin{array}{l}\text { Saya bertekad berali dari paket data ke berlangganan wifi }\left(\mathrm{X}_{4.1 .1}\right) \\
\text { Beralih }\end{array}$ & $\begin{array}{l}\text { Saya memiliki keinginan yang tinggi untuk beralih ke berlangganan wifi } \\
\left(\mathrm{X}_{4.1 .2}\right) \\
\text { Saya memertimbangkan untuk beralih ke berlangganan wifi }\left(\mathrm{X}_{4.1 .3}\right)\end{array}$ \\
\hline
\end{tabular}

Sumber: Data diolah (2020)

Tabel 2.

KARAKTERISTIK RESPONDEN

\begin{tabular}{llcc}
\hline & Karakteristik & Jumlah & Persentase \\
\hline Jenis Kelamin & Pria & 59 & $45 \%$ \\
Usia & Wanita & 61 & $55 \%$ \\
& 20-25 Tahun & 97 & $88 \%$ \\
& 26-30 Tahun & 9 & $8 \%$ \\
& 31-35 Tahun & 3 & $3 \%$ \\
& 36-40 Tahun & 1 & $1 \%$ \\
Pendidikan Terakhir & $>40$ Tahun & - & $0 \%$ \\
& SMA & 77 & $70 \%$ \\
& Diploma & 2 & $2 \%$ \\
& Sarjana & 31 & $28 \%$ \\
& Mahasiswa & 69 & $63 \%$ \\
& PNS & 2 & $2 \%$ \\
Pengeluaran Per Bulan & Pegawai Swasta & 23 & $21 \%$ \\
& Wirausaha & 16 & $15 \%$ \\
& <Rp1.000.000 & 47 & $43 \%$ \\
& Rp1.000.001-Rp2.000.000 & 38 & $35 \%$ \\
& Rp2.000.001-Rp3.000.000 & 11 & $10 \%$ \\
& Rp3.000.001-Rp4.000.000 & 8 & $7 \%$ \\
& $>$ Rp4.000.000 & 6 & $5 \%$ \\
\hline
\end{tabular}

Sumber: Data diolah (2020)

\section{Uji Validitas dan Reliabilitas}

Dalam uji validitas dan reliabilitas pada penelitian ini dilakukan dengan membagikan kuesioner kepada responden secara online melalui google form. Item pernyataan dapat dikatakan valid apabila $r$ hitung > $\mathrm{r}$ tabel $(0,30)$ dan reliabel apabila nilai cronbach alpha $>0,70$. Berdasarkan hasil analisis uji validitas menunjukkan bahwa ada beberapa item dalam kuesioner penelitian ini terbukti memiliki $r$ hitung $<r$ tabel sehingga dinyatakan tidak valid. Namun, untuk jumlah pernyataan nilai $r$ hitung $>r$ tabel $(0,30)$ lebih banyak sehingga dapat digunakan untuk melakukan pengukuran pengaruh push, pull dan mooring terhadap switching intention. Hasil uji reliabilitas menunjukkan bahwa seluruh item dalam kuesioner ini memiliki nilai cronbach alpha $>0,70$. Sehingga item pernyataan pada instrumen penelitian dinyatakan valid dan reliabel sebagai alat ukur pengaruh push, pull dan mooring terhadap switching intention.

\section{Uji Asumsi Klasik}

Uji regresi linier yang digunakan merupakan uji normalitas dengan uji Kolmogrov-Smirnov, pada nilai sig. (2-tailed) memiliki nilai 0,177. Hasil uji normalitas memenuhi nilai signifikansi lebis besar 0,05, sehingga berdistribusi normal. Persyaratan selanjutnya yaitu uji multikolinieritas dengan nilai tolerance dari push, pull, dan mooring yaitu $2,052 \geq 0,01$. Selanjutnya yaitu nilai VIF (Variance Inflation factor) dari push-pull-mooring yaitu 4,541 $\leq 10$. Artinya memenuhi asumsi multikolinieritas. Uji persyaratan yang terakhir yaitu uji heterokedasitas dengan uji Spearman's rho, hasil koefisien menunjukkan signifikansi pada variabel push 0,08 , variabel pull 0,321, dan variabel mooring 0,916 . Hasil masingmasing menunjukkan residual lebih besar 0,05 yang artinya memenuhi asumsi heterokedasitas. 


\section{Pengujian Hipotesis}

\section{Tabel 3.}

\section{HASIL UJI REGRESI LINIER BERGANDA}

\begin{tabular}{cccccc}
\hline Model & B & Error & t & sig & Keterangan \\
\hline Konstanta & 1.350 & 1.396 & .967 & .336 & \\
Push effect & .300 & .014 & 2.250 & .027 & Ha diterima \\
Pull effect & .324 & .044 & 7.379 & .000 & Ha diterima \\
Mooring effect & -.067 & .060 & -1.114 & .268 & Ha ditolak \\
\hline
\end{tabular}

Sumber: Data diolah (2020)

Berdasarkan tabel 3, diperoleh persamaan regresi linear berganda pada rumus (1). Pada rumus (1), Y mewakili switching intention, X1 mewakili push, X2 mewakili pull, dan X3 mewakili mooring. Hasil persamaan (1) diinterpretasikan terdapat nilai konstanta 1,350. Artinya, dengan adanya push, pull, dan mooring maka konsumen akan melakukan switching intention pada produk wifi. Nilai koefisien push effect (X1) sebesar 0,300. Apabila push effect yang didapatkan responden semakin tinggi, maka switching intention responden dari internet paket data akan semakin tinggi untuk beralih ke wifi pribadi. Kemudian nilai koefisien pull effect (X2) sebesar 0,324. Jika pull effect dari wifi pribadi semakin tinggi, maka akan semakin tinggi switching intention responden meninggalkan internet paket data. Sedangkan, nilai koefisien mooring effect (X3) adalah (-0,067). Menjelaskan, jika semakin tinggi mooring effect yang didapatkan responden maka akan menurunkan switching intention responden internet paket data ke wifi pribadi. Sebaliknya semakin rendah mooring effect yang didapatkan responden maka akan meningkatkan responden untuk switching intention ke wifi pribadi.

$\mathrm{Y}=1,350+0,30 \mathrm{X}_{1}+0,324 \mathrm{X}_{2}-0,067 \mathrm{X}_{3}$

Pada tabel 3, dijelaskan bahwa push memiliki nilai t-hitung sebesar 0,967 dengan signifikansi 0,027 di mana nilai tersebut memiliki nilai lebih kecil dari 0,05. Nilai tersebut menjelaskan bahwa push berpengaruh terhadap switching intention, maka $\mathrm{H} 1$ diterima. Hasil penelitian menunjukkan pull memiliki nilai t-hitung 7,379 dengan signifikansi 0,000 sehingga memiliki nilai lebih kecil dari 0,05 bahwa pull berpengaruh pada switching intention sehingga $\mathrm{H} 2$ diterima Penelitian ini membuktikan bahwa mooring memiliki nilai t-hitung $-1,114$ dengan signifikansi 0,268 itu menunjukkan nilai lebih besar dari 0,05 dapat dijelaskan mooring tidak berpengaruh terhadap switching intention, maka $\mathrm{H} 3$ ditolak.

\section{Uji Kelayakan Model (Adjust R Square)}

Hasil pada pengaruh push, pull dan mooring terhadap switching intention menghasilkan $\mathrm{R}$ (korelasi) dan $\mathrm{R}^{2}$ (Adjusted $R$ Square). Pada tabel 3 dijelaskan bahwa nilai kontribusi atau nilai Adjusted $R$ Square untuk variabel independen push (X1), pull (2), dan mooring (X) terhadap variabel dependen switching intention (Y) sebesar 0,419 atau sebesar $41 \%$. Artinya push, pull dan mooring memiliki proporsi pengaruh terhadap switching intention sebesar $41 \%$ dan sisanya dipengaruhi oleh variabel lain yang tidak termasuk dalam penelitian ini.

\section{Pengaruh Push Effect terhadap Switching Intention}

Hasil penelitian menunjukkan variabel push memiliki pengaruh positif terhadap switching intention dari konsumen internet paket data ke wifi pribadi. Hal tersebut artinya bahwa jika push effect meningkat atau menurun akan terjadi pengaruh yang searah pada switching intention. Hasil penelitian ini mampu membuktikan konsep Moon (1995) yang menyatakan bahwa push effect berpengaruh secara positif terhadap switching intention konsumen. Penelitian ini sejalan dengan hasil penelitian terdahulu yang dilakukan oleh Bansal et al. (2005) menjelaskan bahwa push berpengaruh positif pada switching intention. Penelitian ini juga mendukung penelitian terdahulu yang dilakukan Lai et al. (2012) bahwa push memengaruhi secara positif terhadap niat beralih. Hasil dari penelitian ini juga mendukung penelitian dari Chang et al. (2017) menyatakan bahwa push dapat memengaruhi positif untuk switching. 
Adita Primadana Sugandha \& Tias Andarini Indarwati. Pengaruh Push, Pull, dan Mooring terhadap Switching Intention pada Konsumen Pengguna Wifi di Era Pandemi Covid-19

Hasil penelitian ini selaras dengan penelitian yang dilakukan Wu et al. (2017) bahwa push berpengaruh secara positif pada switching intention.

Penelitian ini menunjukkan bahwa responden sebagai konsumen internet paket data menyatakan tidak puas terkait dengan layanan yang diberikan oleh provider internet paket data di Surabaya. Hal ini dikarenakan kecepatan internet paket data yang tidak stabil. Selain itu jika dikalkulasikan, biaya yang dikeluarkan responden untuk membeli internet paket data lebih mahal dibandingkan biaya wifi perbulannya. Di masa pandemi saat ini, mayoritas responden melakukan pekerjaan secara WFH dan sekolah secara online dari rumah (Purwanto et al., 2020). Responden membutuhkan internet yang stabil dan cepat. Karena alasan itu pula, banyak konsumen yang memiliki keinginan switching dari paket internet data ke wifi pribadi.

Responden merasa bahwa penggunaan internet paket data masa pandemi ini kurang memuaskan perihal kualitas layanan yang rendah, masalah harga, kepuasan yang rendah dan rendahnya kepercayaan pada penyedia layanan internet paket data. Hal tersebut membuat responden memiliki switching intention pada wifi pribadi. Responden memiliki switching intention untuk beralih ke wifi pribadi dengan niat beralihnya responden dari internet paket data ke wifi pribadi, responden berharap wifi pribadi lebih baik daripada internet paket data. Menaiknya permintaan konsumen untuk switching merupakan keuntungan pada ISP (Internet Service Provider) (Akurat.co, 2020). Pengelola ISP dapat lebih memperbanyak jangkauan jaringan untuk pemasangan wifi secara pribadi, dengan adanya kondisi pandemi sekarang merupakan kesempatan yang bagus untuk semua pengelola ISP.

\section{Pengaruh Pull Effect terhadap Switching Intention}

Hasil pada penelitian ini variabel pull menunjukkan pengaruh positif yang artinya memiliki pengaruh terhadap switching intention. Menurut teori Bogue, (1969) pull effect merupakan faktor positif yang menarik pengguna layanan untuk ke tujuan tertentu. Hasil penelitian ini sejalan dengan penelitian terdahulu yang dilakukan oleh Bansal et al. (2005) menyatakan variabel pull adalah atribut positif yang menarik pengguna layanan beralih ke tempat tujuan, sehingga pull berpengaruh secara positif terhadap switching. Penelitian terdahulu yang dilakukan oleh Wu et al. (2017) menyatakan ditemukan pengaruh positif terhadap switching. Jung et al. (2017) juga menyatakan bahwa sebuah layanan yang memiliki daya tarik memberikan sebuah tawaran yang lebih baik memberikan kepuasan lebih dapat memengaruhi untuk melakukan switching.

Responden tertarik untuk switching dari internet paket data ke wifi pribadi, dikarenakan pengaruh dari teman-teman konsumen (peer influence) yang menyatakan berlangganan wifi lebih menguntungkan daripada menggunakan internet paket data. Dari pandang sudut konsumen, peer influence merupakan faktor penting pada switching yang dilakukan oleh konsumen internet paket data ke wifi pribadi (J. Y. Lai et al., 2012). Mobilitas responden yang tinggi membuat responden sering menggunakan internet yang cepat dan stabil untuk memenuhi kebutuhannya. Selain menggunakan internet paket data, responden memiliki alternative attractiveness yaitu menggunakan wifi pribadi.

Penggunaan wifi pribadi merupakan daya tarik alternatif (alternative attractiveness) konsumen internet paket data untuk menggunakan internet dengan waktu yang lama, terutama masa pandemi yang membuat mereka sering menggunakan internet untuk hiburan mengurangi stres setelah menyelesaikan pekerjaannya. Pengelola ISP (Internet Service Provider) melakukan promosi atau iklan melalui media sosial dengan menunjukkan promo dan keunggulan. Sehingga ketika pengguna media sosial mengetahui iklan tersebut, maka bisa merekomendasikan ke temannya atau bisa juga menjadi daya tarik alternatifnya untuk beralih dari internet paket data.

\section{Pengaruh Mooring effect terhadap Switching Intention}

Variabel mooring pada penelitian ini tidak memiliki pengaruh pada switching intention. Hal tersebut dapat diartikan, jika mooring effect meningkat atau menurun tidak terjadi pengaruh pada switching intention. Penelitian ini sejalan dengan Pangestu, dan Sanaji, (2020) yang menyatakan mooring effect tidak memiliki pengaruh terhadap variabel customer value migration dari media personal computer kepada smartphone sebagai media untuk bermain online game. Penelitian ini tidak mendukung hasil 
penelitian yang dilakukan oleh Hsieh et al. (2012) yang menyatakan bahwa mooring berpengaruh negatif terhadap switching intention sehingga memperlemah untuk niatan beralih dari tempat asal menuju tempat baru. Hasil penelitian ini juga tidak mampu membuktikan teori yang dilakukan Bansal et al. (2005) yang menyatakan mooring effect dapat menghambat konsumen untuk melakukan switching intention dari penyedia layanan yang digunakan sekarang menuju ke penyedia layanan baru. Penelitian ini juga tidak sejalan dengan penelitian yang dilakukan Jung et al. (2017) bahwa mooring effect mempunyai pengaruh yang paling besar pada konsumen secara negatif terhadap switching intention. Pada penelitian ini juga tidak mendukung penelitian Hou et al. (2011) bahwa mooring effect berpengaruh negatif terhadap switching intention dan memperlemah dorongan maupun tarikan. Hasil penelitan tersebut berbeda dengan hasil penelitian ini yang menggunakan indikator switching costs dan past experience konsumen internet paket data terhadap switching intention wifi. Masa pandemi sekarang tidak memengaruhi responden untuk melakukan penggunaan wifi pribadi meskipun dengan biaya yang terbilang mahal dan responden merasa pengalaman menggunakan wifi di tempat umum memuaskan.

Responden pada penelitian ini mayoritas berusia 20-25 tahun. Pada usia milenial tersebut kecenderungan sering menggunakan gadgetnya untuk mengakses internet dengan keperluan mereka masing-masing, masa pandemi membuat mereka sering mengakses internet untuk menyelesaikan pekerjaan, bersosialisasi dan menggunakannya sebagai hiburan untuk menghilangkan stres maupun kejenuhan (Hootsuite, 2020).

\section{KESIMPULAN}

Hasil penelitian terhadap 110 responden, dapat disimpulkan variabel push pada switching intention penggunaan wifi memiliki pengaruh secara positif, variabel pull berpengaruh positif pada switching intention penggunaan wifi. Ketika dorongan dan tarikan semakin kuat maka konsumen akan switching. Variabel mooring tidak memiliki pengaruh terhadap internet paket data switching intention ke wifi pribadi.

Berdasarkan hasil responden, switching intention dari paket data untuk menggunakan wifi secara pribadi di rumah cukup tinggi. Dikarenakan dengan menggunakan wifi pribadi, dapat mengakses atau menjelajahi internet dengan kecepatan yang stabil dibandingkan dengan internet paket data, berbeda dengan menggunakan internet paket data yang jaringannya tidak stabil. Masa pandemi membuat mayoritas pekerjaan dilakukan secara online di rumah dan mengakses internet, pengguna internet dapat berinteraksi dengan jarak jauh sekaligus juga melakukan hiburan untuk menghilangkan jenuh dengan bermain game atau menggunakan media sosial, sehingga membutuhkan internet yang stabil. Biaya peralihan yang mahal tidak memengaruhi responden untuk switching pada wifi pribadi dan responden memiliki pengalam baik pada penggunaan wifi. Permintaan yang tinggi dari konsumen, perusahaan ISP seharusnya memperluas jangkauan daerah untuk memenuhi permintaan konsumen. Dikarenakan masa pandemi ini konsumen membutuhkan internet, semakin tinggi permintaan maka semakin tinggi persaingan perusahaan ISP. Memberikan harga promo pada konsumen merupakan salah satu cara untuk menarik konsumen agar menggunakan penyedia layanan ISP tersebut.

Pada penelitian ini terdapat kekurangan, referensi penelitian yang terdahulu perihal switching intention dari internet paket data menggunakan wifi masih terbatas, penelitian ini tidak menggunakan moderasi dan penyebaran kuesioner hanya secara online. Dalam penelitian selanjutnya diharapkan dapat melakukan penelitian lebih lanjut mengenai pengaruh push, pull dan mooring terhadap switching intention dari internet paket data pada wifi. Penelitian selanjutnya dapat juga menggunakan kuesioner secara offline dan online untuk mendapatkan data informasi yang lebih luas.

\section{DAFTAR PUSTAKA}

Akurat.co. (2020). Riset: Permintaan Layanan Internet Meningkat Saat Pandemi. Akurat.Co. (https://akurat.co/riset-permintaan-layanan-internet-meningkat-saat-pandemi?page=all diakses pada 15 Juli 2021) 
Adita Primadana Sugandha \& Tias Andarini Indarwati. Pengaruh Push, Pull, dan Mooring terhadap Switching Intention pada Konsumen Pengguna Wifi di Era Pandemi Covid-19

Bansal, H. S., Taylor, S. F., \& James, Y. S. (2005). "Migrating" to new service providers: Toward a unifying framework of consumers' switching behaviors. Journal of the Academy of Marketing Science, 33(1), 96-115. https://doi.org/10.1177/0092070304267928

Bogue, D. J. (1969). Principles of demography. New York: John Wiley.

Bolye, P.J. and Halfacree, K. (1998). Migration and Gender in the Developed World. New York: Longman Press.

Chang, H. H., Wong, K. H., \& Li, S. Y. (2017). Applying push-pull-mooring to investigate channel switching behaviors: M-shopping self-efficacy and switching costs as moderators. Electronic Commerce Research and Applications, 24, 50-67. https://doi.org/10.1016/j.elerap.2017.06.002

Chiu, H. C., Hsieh, Y. C., Roan, J., Tseng, K. J., \& Hsieh, J. K. (2011). The challenge for multichannel services: Cross-channel free-riding behavior. Electronic Commerce Research and Applications, 10(2), 268-277. https://doi.org/10.1016/j.elerap.2010.07.002

Databoks.katadata.co.id (2020). Orang Indonesia Habiskan Hampir 8 Jam untuk Berinternet. Databooks.Katadata.Co.Id. (https://databoks.katadata.co.id/datapublish/2020/02/26/indonesiahabiskan-hampir-8-jam-untuk-berinternet diakses pada 20 Juli 2021)

Djkn.kemenkeu. (2020). WFH di Tengah Pandemi COVID-19. Djkn.Kemenkeu. (https://www.djkn.kemenkeu.go.id/kpknl-jakarta1/baca-artikel/13177/WFH-di-Tengah-

Pandemi-COVID-19.html diakses pada 15 Juli 2021)

Gajimu.com. (2020). FAQ Seputar Ketenagakerjaan Terkait Pandemi COVID-19. Gajimu.Com. (https://gajimu.com/tips-karir/kondisi-kerja-dan-kehidupan-di-tengah-pandemi-covid-19indonesia/faq-ketenagakerjaan-dan-covid-19 diakses pada 15 Juli 2021)

Ganesh, J., Arnold, M. J., \& Reynolds, K. E. (2000). Understanding the customer base of service providers: An examination of the differences between switchers and stayers. Journal of Marketing, 64(3), 65-87. https://doi.org/10.1509/jmkg.64.3.65.18028

Gizmologi.id. (2019). perbedaan-koneksi-wifi-data-seluler-pada-smartphone. Gizmologi.Id. (https://gizmologi.id/news/tech/perbedaan-koneksi-wifi-data-seluler-pada-smartphone/ diakses pada 15 Juli 2021)

Hou, A. C. Y., Chern, C. C., Chen, H. G., \& Chen, Y. C. (2009). Using demographic migration theory to explore why people switch between online games. Proceedings of the 42nd Annual Hawaii International Conference on System Sciences, HICSS, 1-9. https://doi.org/10.1109/HICSS.2009.493

Hou, A. C. Y., Chern, C. C., Chen, H. G., \& Chen, Y. C. (2011). "Migrating to a new virtual world": Exploring MMORPG switching through human migration theory. Computers in Human Behavior, 27(5), 1892-1903. https://doi.org/10.1016/j.chb.2011.04.013

Hsieh, J. K., Hsieh, Y. C., Chiu, H. C., \& Feng, Y. C. (2012). Post-adoption switching behavior for online service substitutes: A perspective of the push-pull-mooring framework. Computers in Human Behavior, 28(5), 1912-1920. https://doi.org/10.1016/j.chb.2012.05.010

Jasmine, C. A. (2020). Impacts of Covid-19 on Company and Efforts to Support Organization Adaptable. SSRN Electronic Journal, April. https://doi.org/10.2139/ssrn.3590726

Jones, M. A., Mothersbaugh, D. L., \& Beatty, S. E. (2000). Switching barriers and repurchase intentions in services. Journal of Retailing, 76(2), 259-274. https://doi.org/10.1016/S0022-4359(00)00024- 
Jung, J., Han, H., \& Oh, M. (2017). Travelers' switching behavior in the airline industry from the perspective of the push-pull-mooring framework. Tourism Management, 59, 139-153. https://doi.org/10.1016/j.tourman.2016.07.018

Keaveney, S. M. (1995). Customer Switching Behavior in Service Industries: An Exploratory Study. Journal of Marketing, 59(2), 71. https://doi.org/10.2307/1252074

Kim, M. K., Park, M. C., \& Jeong, D. H. (2004). The effects of customer satisfaction and switching barrier on customer loyalty in Korean mobile telecommunication services. Telecommunications Policy, 28(2), 145-159. https://doi.org/10.1016/j.telpol.2003.12.003

Lai, F., Griffin, M., \& Babin, B. J. (2009). How quality, value, image, and satisfaction create loyalty at a Chinese telecom. Journal of Business Research, 62(10), 980-986. https://doi.org/10.1016/j.jbusres.2008.10.015

Lai, J. Y., Debbarma, S., \& Ulhas, K. R. (2012). An empirical study of consumer switching behaviour towards mobile shopping: A Push-Pull-Mooring model. International Journal of Mobile Communications, 10(4), 386-404. https://doi.org/10.1504/IJMC.2012.048137

Malhotra, N. . (2009). Riset Pemasaran. Jakarta: PT. Indeks.

Mcalister, L. (2012). Variety-Seeking Substitute Identify Relationships Complementary to Competing Products. Journal of Marketing, 22(3), 330-339.

Moon, B. (1995). Paradigms in migration research: Exploring 'moorings' as a schema. Progress in Human Geography, 19(4), 504-524. https://doi.org/10.1177/030913259501900404

Newssetup.kontan.co.id. (2021). wfh-bikin-pelanggan-wifi-republic-meningkat-drastis. Newssetup.Kontan.Co.Id. (https://newssetup.kontan.co.id/news/wfh-bikin-pelanggan-WIrepublic-meningkat-drastis diakses pada 15 Juli 2021)

Pangestu, L., \& Sanaji, S. (2020). Customer value migration pada platform bermain online games. KINERJA, 17(2), 215-221.

Parthasarathy, M., \& Keaveney, S. M. (2001). Customer Switching Behavior in Online Services: An Exploratory Study of the Role of Selected Attitudinal, Behavioral, and Demographic Factors. Journal of the Academy of Marketing Science, 29(4), 374-390.

Purwanto, A., Asbari, M., Fahlevi, M., Mufid, A., Agistiawati, E., Cahyono, Y., \& Suryani, P. (2020). Impact of Work From Home (WFH) on Indonesian Teachers Performance During the Covid-19 Pandemic : An Exploratory Study. International Journal of Advanced Science and Technology, 29(5), 6235-6244.

Putri, A. V., \& Irwansyah, I. (2020). Communication Patterns and Media Technology Role in Organization and Society During Pandemic. The Journal of Society and Media, 4(2), 228-261. https://doi.org/10.26740/jsm.v4n2.p228-261

Retaildive.com. (2017). Why social shopping is the next big thing for mobile. Retail Dive.com. (https://www.retaildive.com/ex/mobilecommercedaily/why-social-shopping-is-the-next-bigthing-for-mobile diakses pada 18 Juli 2021

Thaichon, P., Lobo, A., Prentice, C., \& Quach, T. N. (2014). The development of service quality dimensions for internet service providers: Retaining customers of different usage patterns. 
Adita Primadana Sugandha \& Tias Andarini Indarwati. Pengaruh Push, Pull, dan Mooring terhadap Switching Intention pada Konsumen Pengguna Wifi di Era Pandemi Covid-19

Journal of Retailing and Consumer Services, 21(6), 1047-1058. https://doi.org/10.1016/j.jretconser.2014.06.006

Wu, K., Vassileva, J., \& Zhao, Y. (2017). Understanding users' intention to switch personal cloud storage services: Evidence from the Chinese market. Computers in Human Behavior, 68, 300314. https://doi.org/10.1016/j.chb.2016.11.039

Ye, C., \& Potter, R. (2011). The role of habit in post-adoption switching of personal information technologies: An empirical investigation. Communications of the Association for Information Systems, 28(1), 585-610. https://doi.org/10.17705/1cais.02835

Zengyan, C., Yinping, Y., \& Lim, J. (2009). Cyber migration: An empirical investigation on factors that affect users? Switch intentions in social networking sites. Proceedings of the 42nd Annual Hawaii International Conference on System Sciences, HICSS, 1-11. https://doi.org/10.1109/HICSS.2009.140

Zhao, Y. L., \& Di Benedetto, C. A. (2013). Designing service quality to survive: Empirical evidence from Chinese new ventures. Journal of Business Research, 66(8), 1098-1107. https://doi.org/10.1016/j.jbusres.2012.03.006 